\title{
Late-Season Weed Management to Stop Viable Weed Seed Production
}

\author{
Erin C. Hill, Karen A. Renner, Mark J. VanGessel, Robin R. Bellinder, and Barbara A. Scott*
}

Integrated weed management (IWM) for agronomic and vegetable production systems utilizes all available options to effectively manage weeds. Late-season weed control measures are often needed to improve crop harvest and stop additions to the weed seed bank. Eliminating the production of viable weed seeds is one of the key IWM practices. The objective of this research was to determine how termination method and timing influence viable weed seed production of late-season weed infestations. Research was conducted in Delaware, Michigan, and New York over a 2-yr period. The weeds studied included: common lambsquarters, common ragweed, giant foxtail, jimsonweed, and velvetleaf. Three termination methods were imposed: cutting at the plant base (simulating hand hoeing), chopping (simulating mowing), and applying glyphosate. The three termination timings were flowering, immature seeds present, and mature seeds present. Following termination, plants were stored in the field in mesh bags until mid-Fall when seeds were counted and tested for viability. Termination timing influenced viable seed development; however, termination method did not. Common ragweed and giant foxtail produced viable seeds when terminated at the time of flowering. All species produced some viable seed when immature seeds were present at the time of termination. The time of viable seed formation varied based on species and site-year, ranging from plants terminated the day of flowering to 1,337 growing degree $\mathrm{d}$ after flowering (base 10,0 to 57 calendar d). Viable seed production was reduced by 64 to $100 \%$ when common lambsquarters, giant foxtail, jimsonweed, and velvetleaf were terminated with immature seeds present, compared to when plants were terminated with some mature seeds present. Our results suggest that terminating common lambsquarters, common ragweed, and giant foxtail prior to flowering, and velvetleaf and jimsonweed less than 2 and 3 wk after flowering, respectively, greatly reduces weed seed bank inputs. Nomenclature: Common lambsquarters, Chenopodium album L.; common ragweed, Ambrosia artemiisifolia L.; giant foxtail, Setaria faberi Herrm.; jimsonweed, Datura stramonium L.; velvetleaf, Abutilon theophrasti Medik.

Key words: Anthesis, germination, seed bank, seed development, seed set, termination.

Farmers in conventional and organic agronomic and vegetable production systems rely on cultural, mechanical, and chemical management tactics to stop weed emergence, growth, and seed production. Despite the best efforts of farmers, monetary losses due to weeds in 2010 were estimated to be over 2.6 billion dollars in the United States (Davis 2013). Weeds that emerge with the crop are the most competitive and have the potential to produce thousands of seeds per plant (Bagavathiannan and Norsworthy 2012). Seeds can persist in the seed bank from one season to the next, furthering future weed infestations. Spread of weeds, both within fields and between fields, often occurs as a result of

\footnotetext{
DOI: $10.1614 /$ WS-D-15-00096.1

* First and second authors: Research Associate and Professor, Department of Plant, Soil and Microbial Sciences, Michigan State University, East Lansing, MI 48824; third and fifth authors: Professor and Research Associate, Department of Plant and Soil Science, University of Delaware, Georgetown, DE 19947; fourth author: Professor, Department of Horticulture, Cornell University, Ithaca, NY 14853. Corresponding author's E-mail: hiller12@msu.edu
}

seed dispersal and movement (Davis et al. 2005). Stopping weed seed production is critical to reducing the spread and the costs associated with all weed infestations in cropping systems (Bell and Tranel 2010).

In Northeast cropping systems, which include a variety of agronomic and vegetable row crops, lateseason weed control measures (i.e., mid-July through harvest) are aimed at reducing future weed infestations and increasing harvest efficiency because competition with the crop has often already occurred (McErlich and Boydston 2013). Methods of late-season control include herbicide applications, handweeding (pulling and hoeing), mowing, and harvest-time weed seed control (HWSC) systems. Herbicides applied as harvest aids at the time of crop maturity desiccate weed foliage and reduce grain moisture at harvest, but many weeds have mature seed at this time (Bennett and Shaw 2000; Griffin et al. 2010). Late-season herbicide applications can reduce weed seed production. For example, a single glyphosate application to soybean [Glycine $\max (\mathrm{L}$.$) Merr.] later in the season (applied to all$ 
at the time of pitted morningglory [Ipomoea lacunosa L.] flowering) suppressed seed production of pitted morningglory, barnyardgrass [Echinochloa crus-galli (L.) Beauv.], Palmer amaranth (Amaranthus palmerii S. Wats.), prickly sida (Sida spinosa L.), and sicklepod [Senna obtusifolia (L.) H. S. Irwin \& Barneby] by 83 to $99 \%$ (Walker and Oliver 2008). Pitted morningglory seed production was also reduced by a single glufosinate application $14 \mathrm{~d}$ before soybean harvest (Bennett and Shaw 2000), although glufosinate is not currently labeled for use on soybeans at this timing. Hand-weeding (i.e., pulling or hoeing) and mowing have been tactics utilized by organic growers to manage weeds and reduce weed seed bank inputs for many years (McErlich and Boydston 2013). More recently, hand-pulling weeds and removing them from the field prior to weed seed production has become an important tactic for reducing herbicide-resistant Palmer amaranth seed banks in the southern United States (Riar et al. 2013). HWSC systems include destroying the weed seedbearing chaff fraction at the time of harvest by pulverizing the seed (Walsh and Powles 2014) or removing weed and crop residue containing seeds after baling or windrowing and burning the residue (Walsh and Newman 2007; Walsh and Powles 2007). The HWSC systems were developed in Australia where widespread herbicide resistance in rigid ryegrass (Lolium rigidum Gaudin) has devastated the Western Australian wheat belt for several years (Llewellyn and Powles 2001; Walsh and Powles 2007). Seed must remain on the standing weeds at the time of crop harvest for these systems to be effective.

The time to viable seed formation has been studied in detail for some weed species and is necessary information for scheduling of late-season weed management. Seed of dandelion (Taraxacum officinale G. H. Weber ex Wiggers), jimsonweed (Datura stramonium L.), annual sowthistle (Sonchus oleraceus L.), common groundsel (Senecio vulgaris L.), and tansy ragwort (Senecio jacobaea L.) were collected from plants cut off at ground level at flowering through mature seed formation (Gill 1938). Mature, germinable seeds formed in sowthistle, groundsel, and ragwort when terminated at flowering; however, jimsonweed did not produce viable seed when terminated prior to the milk/fruit stage, and dandelion did not produce viable seed until mature seed formation. In more recent dandelion research, viable seed was dispersed 8 to $13 \mathrm{~d}$ after the closing of the bracts at the end of flowering period (Martinkova et al. 2011).
Seed maturation has been studied in some weedy species more frequently found in the southern United States, including prickly sida, pitted morningglory, purple moonflower (Ipomoea turbinata Lag.), and tall waterhemp [Amaranthus tuberculatus (Moq.) Sauer]. Prickly sida had viable seed $12 \mathrm{~d}$ after anthesis (Egley 1976), waterhemp $14 \mathrm{~d}$ after pollination (Bell and Tranel 2010), and morningglory spp. $20 \mathrm{~d}$ after anthesis (Chandler et al. 1977; Jayasuriya et al. 2007). Time of flowering for pitted morningglory, common cocklebur (Xanthium strumarium L.), and sicklepod were influenced by photoperiod and temperature (Senseman and Oliver 1993).

Many weed species are short-day plants with flowering beginning after the summer solstice as daylength decreases (Deen et al. 1998; Dekker et al. 1996; Huang et al. 2001; Warwick and Black 1988). In greenhouse research, Benvenuti et al. (1994) reported growing degree day (GDD) requirements for flowering and seed formation (defined as fruits beginning to mature) for johnsongrass [Sorghum halepense (L.) Pers.], jimsonweed, and velvetleaf, and reported that shading lengthened GDDs by $10 \%$. Seed maturation field studies are limited for weeds that infest northern U.S. crop production systems, including grass species. Winter (1960) reported mature velvetleaf seeds within $20 \mathrm{~d}$ of pollination; Anderson (1997) reported 40\% seed viability in longspine sandbur [Cenchrus longispinus (Hack.) Fern.] at anthesis.

For the weed species studied to date, the 2- to 3wk period after anthesis is the critical time for management interventions to stop weeds from producing viable seed. However, how the weeds are "stopped" or "terminated" can influence the time period for implementing seed bank control. In Western Australia, Dodd (1989) compared seed development in blessed milkthistle [Silybum marianum (L.) Gaertn.] and found that the method of termination affected the number of seeds reaching maturity. Plants that were cut off at ground level and chopped into fragments produced fewer mature seeds than plants that were only cut off at ground level. If viable weed seed continue to develop on plants that have been cut, mowed, or treated with a herbicide, farmers might need to apply late-season weed management practices earlier than biological studies indicate. Therefore the objectives of this research were to determine the reproductive growth stage (days after anthesis) at which common northern U.S. summer annual weeds could be terminated and not produce viable seeds; and secondly, to

Hill et al.: Postmanagement seed viability • 113 
Table 1. Species, termination timing, method descriptions, and replications for study locations in Delaware, Michigan, and New York.

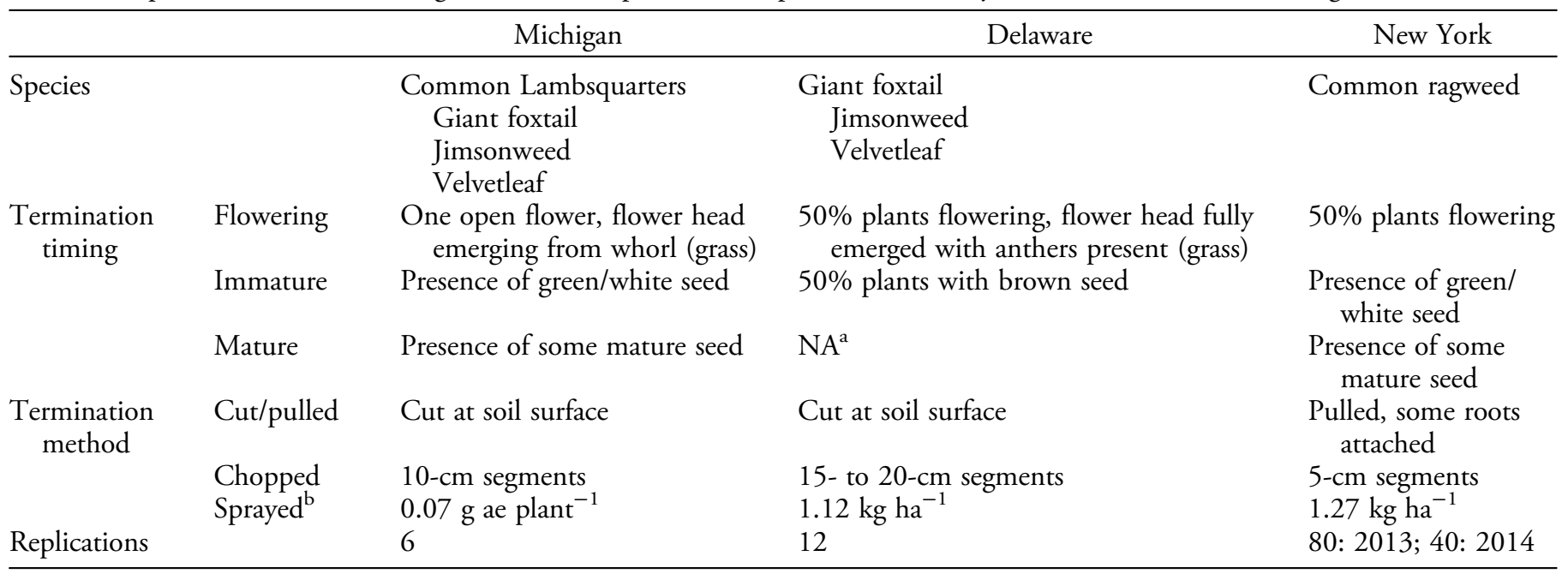

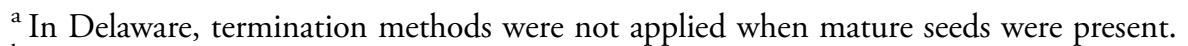

${ }^{\mathrm{b}}$ Glyphosate application rate/method.

determine if the method of weed termination influenced viable seed production.

\section{Materials and Methods}

Field research was conducted at the Michigan State University Agronomy Farm in Lansing, MI in 2011 and 2012 (MI), the University of Delaware Carvel Research and Education Center in Georgetown, DE in 2012 and 2013 (DE), and the Cornell University H. C. Thompson Vegetable Research Farm in Freeville, NY in 2013 and 2014 (NY). The experiment was designed as a three-way factorial with 6,12 , and 80/40 replications at MI, DE, and NY (2013/2014), respectively. Factors included weed species, termination timing, and termination method (Table 1).

This study was a collaborative effort within the Northeast Regional Project NE-1047 Working Group: "Ecological Basis for Weed Management in Sustainable Cropping Systems" with methods varying slightly by location due to personnel and resource limitations. Weed species studied included: common lambsquarters (MI only), common ragweed (NY only), giant foxtail (MI and DE), jimsonweed (MI and DE), and velvetleaf (MI and DE). Weeds were chosen to represent a cross-section of the most prevalent summer annual weeds in the Northeast region of the United States. Plants were selected from naturally occurring fallow areas in NY and in naturally occurring infestations in corn and soybean fields in MI. Weeds were germinated in the greenhouse in DE and transplanted into a soybean field when seedlings were 8 to $15 \mathrm{~cm}$ in height.
At each sampling time, plants were chosen to represent the spectrum of plant sizes (based on height, number of reproductive structures present, etc.) present, and plants were assigned to replications based on size. The second factor was termination timing and included: flowering (except common lambsquarters), immature seeds present, and mature seeds present (MI and NY only). Determining the onset of anthesis for weed species can be difficult, particularly for those with inconspicuous flowers; therefore, the definition of these timings varied slightly by location as subsequently described. Flowering plants were selected with a minimum of 1 open flower plant ${ }^{-1}$ and no advanced reproductive structures for jimsonweed and velvetleaf in MI, and with $50 \%$ of plants at flowering in DE. Flowering common ragweed plants in NY were terminated when $50 \%$ of the plants were flowering. Flowering giant foxtail plants had a single flower head emerging from the whorl in MI; $50 \%$ of the plants had a fully emerged flower head with anthers present in DE. Immature weeds were selected with green or white seeds present and no brown seeds in MI and NY, and with $50 \%$ of the plants with brown seeds present in DE. Mature plants were terminated at the initial appearance of black or fully mature seeds for all species in MI and NY. Lastly, the third factor was termination method, and included: cutting at the base of the plant (i.e., simulating hand hoeing), chopping the whole plant into 5- to 20 -cm segments (i.e., simulating mowing), and applying glyphosate. Cut plants in DE and MI were severed as close to the soil surface as possible using hand pruners. In NY common ragweed was pulled, therefore some roots were still attached. 
Table 2. Local weather conditions in Michigan (MI), Delaware (DE), and New York (NY) during the period of the study, May to October/November. Weed terminations generally began in late July to early August, with field storage ending in mid-October (DE and NY) or early November (MI).

\begin{tabular}{|c|c|c|c|c|c|c|c|c|c|c|c|c|c|c|c|}
\hline \multirow[b]{2}{*}{ Location } & \multirow[b]{2}{*}{ Year } & \multicolumn{2}{|c|}{ May } & \multicolumn{2}{|c|}{ June } & \multicolumn{2}{|c|}{ July } & \multicolumn{2}{|c|}{ August } & \multicolumn{2}{|c|}{ September } & \multicolumn{2}{|c|}{ October } & \multicolumn{2}{|c|}{ November } \\
\hline & & $\mathrm{T}^{\mathrm{a}}$ & $\mathrm{P}^{\mathrm{b}}$ & $\mathrm{T}$ & $\mathrm{P}$ & $\mathrm{T}$ & $\mathrm{P}$ & $\mathrm{T}$ & $\mathrm{P}$ & $\mathrm{T}$ & $\bar{P}$ & $\mathrm{~T}$ & $\bar{P}$ & $\mathrm{~T}$ & $\overline{\mathrm{P}}$ \\
\hline \multirow[t]{3}{*}{ MI } & 2011 & $20 / 10$ & 14 & $25 / 14$ & 4 & $30 / 18$ & 13 & $27 / 13$ & 8 & $21 / 11$ & 7 & $17 / 5$ & 8 & $11 / 1$ & \\
\hline & & $23 / 10$ & 6 & $27 / 14$ & 3 & $31 / 18$ & 4 & & & $23 / 10$ & & $15 / 5$ & & $8 /-2$ & \\
\hline & 30-yr. avg. & $21 / 8$ & 8 & $26 / 13$ & 8 & $28 / 15$ & 8 & $27 / 14$ & 8 & $73 / 9$ & 9 & $23 / 4$ & 7 & $8 /-1$ & \\
\hline \multirow[t]{3}{*}{$\mathrm{DE}$} & 2012 & $24 / 14$ & 8 & $28 / 16$ & 3 & $32 / 21$ & 5 & $29 / 20$ & 13 & $25 / 14$ & 8 & $20 / 8$ & 22 & - & - \\
\hline & & & 6 & $28 / 18$ & 27 & $30 / 21$ & 15 & & 15 & & 2 & $20 / 10$ & 14 & - & - \\
\hline & 30 -yr. avg. & $23 / 12$ & 9 & $28 / 17$ & 12 & $31 / 20$ & 11 & $29 / 19$ & 9 & $26 / 15$ & 10 & $20 / 9$ & 9 & - & - \\
\hline \multirow[t]{3}{*}{ NY } & 2013 & $32 /-4$ & 7 & $31 / 3$ & 7 & $32 / 8$ & 8 & $29 / 6$ & 19 & $31 / 0$ & 8 & $27 /-3$ & 9 & - & 一 \\
\hline & 2014 & $29 /-1$ & 8 & $29 / 6$ & 16 & $31 / 7$ & 10 & $28 / 6$ & 13 & $29 / 1$ & 7 & $24 /-3$ & 7 & - & \\
\hline & 30-yr. avg. & $20 / 6$ & 4 & $24 / 12$ & 4 & $27 / 14$ & 4 & $26 / 14$ & 4 & $22 / 9$ & 4 & $15 / 4$ & 4 & - & \\
\hline
\end{tabular}

${ }^{a}$ Average monthly temperatures $(\mathrm{T})$ maximum/minimum in degrees $\mathrm{C}$.

${ }^{\mathrm{b}}$ Total monthly precipitation $(\mathrm{P})$ in $\mathrm{cm}$.

Chopped plants were cut at the soil surface and then further cut using the hand pruners into segments 5 $\mathrm{cm}, 10 \mathrm{~cm}$, or 15 to $20 \mathrm{~cm}$ in length in NY, MI, and DE, respectively. Glyphosate was applied as a $0.07 \mathrm{~g}$ ae plant ${ }^{-1}$ in MI and at a rate of $1.12 \mathrm{~kg}$ $\mathrm{ha}^{-1}$ and $1.27 \mathrm{~kg} \mathrm{ha}^{-1}$ in DE and NY, respectively. Following termination, plants were either stored in no-seeum mesh bags (Outdoor Wilderness Fabrics, Nampa, ID) lying between rows of a soybean field (cut and chop) or were staked to remain standing and enclosed in a mesh bag (glyphosate application). Bags were retrieved in mid-fall of each year (midOctober in DE and NY, early-November in MI) and dried in the greenhouse. Upon collection, bags often were dirty from rain splatter and fallen soybean debris, the weeds inside the bags appeared completely desiccated, and rarely were samples visibly moldy. Growing season and in-field storage conditions (temperature and precipitation) for each siteyear can be found in Table 2 . After drying samples in the greenhouse, all intact, full seeds were counted. Viability was then tested to determine the total number of viable seeds. In all locations, seed viability was determined through germination, followed by tetrazolium/pressure testing, and included dormant seeds in the total number of viable seeds (Gomez et al. 2014; Hill et al. 2014). In DE and MI, up to 100 seeds plant ${ }^{-1}$ were germinated in the dark at a constant temperature of $25 \mathrm{C}$ (Hill et al. 2014). In $\mathrm{NY}$, common ragweed seeds were first placed on moist filter paper in a cooler at $5 \mathrm{C}$ for $4 \mathrm{wk}$ to break dormancy. Seeds were then germinated in growth chambers with an alternating schedule of $16 / 8 \mathrm{hr}$ dark/light at 20/30 C for 2 wk (Andersen 1968). In MI and NY, seeds that did not germinate were subject to tetrazolium chloride testing using a $0.5 \%$ solution (Peters 2000) and in DE seeds that did not germinate were pressure tested with forceps.

The number of viable seeds (germinated + dormant) produced were analyzed in SAS 9.3 (SAS version 9.3, Institute Inc., Cary, NC) using the MIXED procedure to test for differences among both termination timing and method. Variance assumptions were checked using the UNIVARIATE procedure. The data sets were $\log$-transformed after adding a constant (i.e., 1.1) to compensate for the large number of zero values. Mean separation was conducted using Fisher's Protected LSD $(\mathrm{P} \leq 0.05)$ and back-transformed data are presented. Variations among locations and years lead to multiple interactions; therefore, each species by site-year are presented separately.

\section{Results and Discussion}

Hoeing, mowing, and applying glyphosate resulted in similar viable seed production for all weed species across all timings $(\mathrm{P}>0.05$, data not shown). This is in contrast to Dodd's research on variegated thistle (Dodd 1989), where cut-only plants produced more viable seeds, compared with plants cut and chopped. Glyphosate applied as a preharvest desiccant prior to soybean physiological maturity reduced germination of soybean (Azlin and McWhorter 1981) and sicklepod seed (Bennett and Shaw 2000). The glyphosate application in our research might have produced results similar to the mow/chop treatment because both methods rapidly stop the translocation of photosynthates (Shaner 2009).

Termination timing influenced viable seed production for all weed species. Jimsonweed and velvetleaf did not produce viable seed when terminated at the time of flowering; single open flower or $50 \%$

Hill et al.: Postmanagement seed viability • 115 
Table 3. Total number of viable seeds produced by common Northeastern summer annual weeds terminated at three different growth stages, pooled across termination methods and seedbank reduction based on terminating weeds at the immature seed stage compared to waiting until some mature seed were present.

\begin{tabular}{|c|c|c|c|c|}
\hline \multirow{2}{*}{$\begin{array}{l}\text { Species } \\
\text { Location/Year }\end{array}$} & \multicolumn{3}{|c|}{ Termination timing $^{\mathrm{a}}$} & \multirow{2}{*}{$\begin{array}{l}\text { Seedbank reduction } \\
\text { immature vs. mature }\end{array}$} \\
\hline & Flowering & Immature & Mature $^{b}$ & \\
\hline & 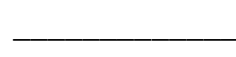 & verage viable seeds) & & $\%$ \\
\hline \multicolumn{5}{|c|}{ Common lambsquarters } \\
\hline MI 2011 & - & $35 \pm 18 \mathrm{a}$ & $6,817 \pm 1,288 b$ & 99.4 \\
\hline MI 2012 & - & $6 \pm 2 a$ & $12,279 \pm 1,438 \mathrm{~b}$ & 100.0 \\
\hline NY $2014^{\mathrm{c}}$ & $\mathrm{Y}$ & $\mathrm{Y}$ & $\mathrm{Y}$ & - \\
\hline \multicolumn{5}{|l|}{ Giant foxtail } \\
\hline MI $2011^{\mathrm{d}}$ & $5 \pm 2$ & $69 \pm 28$ & $191 \pm 34$ & 63.9 \\
\hline MI 2012 & $0 \pm 0 \mathrm{a}$ & $10 \pm 9 a$ & $925 \pm 327 \mathrm{~b}$ & 98.9 \\
\hline DE 2012 & $232 \pm 111$ & - & $4,229 \pm 330^{\mathrm{e}}$ & - \\
\hline DE 2013 & $1,198 \pm 418 \mathrm{a}$ & $7,611 \pm 879 b$ & $16,003 \pm 1,210^{\mathrm{e}}$ & - \\
\hline DE 2013 & $0 \pm 0 \mathrm{a}$ & $3,084 \pm 371 \mathrm{~b}$ & $2,780 \pm 277^{\mathrm{e}}$ & - \\
\hline \multicolumn{5}{|l|}{ Velvetleaf } \\
\hline MI 2011 & $0 \pm 0 \mathrm{a}$ & $0 \pm 0 \mathrm{a}$ & $123 \pm 14 b$ & 100.0 \\
\hline MI 2012 & $0 \pm 0 \mathrm{a}$ & $49 \pm 12 b$ & $607 \pm 112 \mathrm{c}$ & 91.9 \\
\hline DE $2013^{c}$ & $\overline{\mathrm{N}}$ & $\overline{\mathrm{Y}}$ & $\bar{Y}$ & - \\
\hline
\end{tabular}

${ }^{a}$ The values after the means represent the standard errors. Different letters within each row indicate significant differences among the means in that site-year $(\mathrm{P} \leq 0.05)$.

${ }^{\mathrm{b}}$ In Michigan, mature plants were terminated when some mature seed was present using the three methods.

${ }^{\mathrm{c}}$ Abbreviations: N, no viable seed was produced; Y, yes, viable seed was produced (however, total seed numbers are not available).

${ }^{\mathrm{d}}$ An interaction between termination timing and method was observed: hoed, fewer viable seeds at flowering, immature and mature were NS; mowed, each stage had more seeds than the previous; sprayed, no difference among flowering and immature, both fewer than mature.

e In Delaware, mature plants were allowed to reach physiological maturity in the absence of termination and therefore were not included in the statistical analysis.

of plants flowering (Table 3). Common ragweed produced some viable seeds when terminated at $50 \%$ of plants flowering; however, viability was low at 14 and $21 \%$ for 2013 and 2014 , respectively. Giant foxtail also produced viable seeds when terminated at flowering. Plants terminated with flower heads still emerging from the whorl in MI resulted in $<10$ viable seeds plant ${ }^{-1}$. Fully emerged flower heads with anthers present in DE resulted in an average of 232 and 1,198 viable seeds plant ${ }^{-1}$ in 2012 and 2013, respectively. Common lambsquarters was not collected at flowering because of the difficulty in distinguishing between plants that were solely flowering and those that possessed some immature seed. Johnsongrass, jimsonweed, and velvetleaf produced viable seed when terminated 350 , 370 , and 260 GDD (base $10 \mathrm{C}$ ) after flowering in the greenhouse (Benvenuti et al. 1994). In our research, termination times resulting in viable seed formation ranged from 0 to 151 GDD after flowering for giant foxtail (base 10, up to $14 \mathrm{~d}$; 0 GDD indicates that plants terminated on the day of flowering had viable seeds present upon collection in the fall), from 232 to 1,337 GDD (up to $57 \mathrm{~d}$ ) for jimsonweed, and 142 to 374 GDD (up to $13 \mathrm{~d}$ ) for velvetleaf (Table 4). The breadth of the ranges observed in this study is likely the result of timing collections based on the appearance of the seed (i.e., white/green $=$ immature), as opposed to timing collections based on GDD or calendar days. For jimsonweed and velvetleaf in $\mathrm{DE}$, the GDD from flowering to viable seed production might have been higher than in MI and previous greenhouse research because plants were transplanted, and in part because GDD accumulated more rapidly in DE than in MI (Tables 2 and 4).

All weed species studied produced viable seeds when terminated with immature seed present. However, terminating weeds at the immature stage in MI reduced inputs to the seed bank by 64 to $100 \%$, compared with waiting until the onset of maturity 
Table 4. Growing degree days (GDD, base $10 \mathrm{C}$ ) and calendar days (in parentheses) from the time of weed flowering to viable seed production for study locations in Michigan, Delaware, and New York, pooled across termination methods.

\begin{tabular}{|c|c|c|c|c|c|c|}
\hline \multirow[b]{2}{*}{ Species } & \multicolumn{2}{|c|}{ Michigan } & \multicolumn{2}{|c|}{ Delaware } & \multicolumn{2}{|c|}{ New York } \\
\hline & 2011 & 2012 & 2012 & 2013 & 2013 & 2014 \\
\hline & & $-\mathrm{GD}$ & dar days) fro & ng to viable & & \\
\hline Giant foxtail & $0(0)$ & $151(14)$ & $0(0)$ & $0(0)$ & - & - \\
\hline Jimsonweed & $232(21)$ & - & $1,288(49)$ & $1,337(57)$ & - & - \\
\hline Velvetleaf & $202(13)$ & $142(13)$ & - & $374(13)$ & - & - \\
\hline
\end{tabular}

${ }^{a}$ Zero values indicate that viable seeds were found when plants were terminated at the time of flowering. Other values are the GDD, followed by the number of calendar days (in parentheses) from flowering to immature seed, which is when viable seed was found for all species and site-years.

${ }^{\mathrm{b}}$ Common lambsquarters are not included because plants were not collected at the time of flowering.

(Table 3). Seedbank inputs by sicklepod and leafy spurge (Euphorbia esula L.) were reduced when herbicides were applied at the early reproductive stages compared with treating plants with some mature seed (Al-Henaid et al. 1993; Issacs et al. 1989; Taylor and Oliver 1997).

Common lambsquarters and common ragweed emerge early in the spring, whereas giant foxtail and velvetleaf emerge slightly later. All of these species flower following the summer solstice and begin to develop seeds from late June through the remainder of the season (Deen et al. 1998; Dekker et al. 1996; Huang et al. 2001; Myers et al. 2004; Warwick and Black 1988). Early-season weed control is important for reducing crop-weed competition; terminating escaped weeds is critical to reduce the seed bank additions, particularly for early weed cohorts (i. e., those emerging earliest) that have the highest seed production potential. Our research has shown that seed bank additions can be avoided by terminating common lambsquarters, common ragweed, and giant foxtail prior to flowering, whereas jimsonweed and velvetleaf must be terminated within 2 wk of flowering. Information on the timing of emergence and reproductive development (i.e., flowering and seed viability) of weed species in the northern United States is important for developing mechanistic models to describe weed crop competition (Huang et al. 2001), and will aid farmers in stopping the spread of herbicide-resistant and susceptible weed species. Developing guidelines for farmers to remove weeds following flower initiation will improve timing of weed control measures and stop the production of viable seeds in integrated weed management systems.

\section{Acknowledgments}

The authors thank the collaborative efforts of the Northeast Regional Project NE-1047 Working Group:
Ecological Basis for Weed Management in Sustainable Cropping Systems; and Project GREEEN for preliminary funding.

\section{Literature Cited}

Al-Henaid JS, Ferrell MA, Miller SD (1993) Effect of 2,4-D on leafy spurge (Euphorbia esula) viable seed production. Weed Technol 7:76-78

Andersen RN (1968) Germination and Establishment of Weeds for Experimental Purposes. Urbana, IL. Weed Science Society of America. $15 \mathrm{p}$

Anderson RL (1997) Longspine sandbur (Cenchrus longispinus) ecology and interference in irrigated corn (Zea mays). Weed Technol 11:667-671

Azlin WR, McWhorter CG (1981) Preharvest effects of applying glyphosate to soybeans (Glycine max). Weed Sci 29:123-127

Bagavathiannan MV, Norsworthy JK (2012) Late-season seed production in arable weed communities: management implications. Weed Sci 60:325-334

Bell MS, Tranel PJ (2010) Time requirement from pollination to seed maturity in waterhemp (Amaranthus tuberculatus). Weed Sci 58:167-173

Bennett AC, Shaw DR (2000) Effect of preharvest desiccants on weed seed production and viability. Weed Technol 14:530-538

Benvenuti S, Macchia M, Stefani A (1994) Effects of shade on reproduction and some morphological characteristics of Abutilon theophrasti Medicos, Datura stramonium L., and Sorghum halepense L. Pers. Weed Res 34:283-288

Chandler JM, Munson RL, Vaughan CE (1977) Purple moonflower: emergence, growth, reproduction. Weed Sci 25: 163-167

Davis A, Renner K, Sprague C, Dyer L, Mutch D (2005) Integrated Weed Management: "One Year's Seeding..." Michigan State University Extension bulletin E-2931. East Lansing, MI: Michigan State University Extension. Pp 71-77

Davis V (2013) Spread of Herbicide Resistance in Row Crops and Thoughts on the Potential for Future Success of Integrated Weed Management Practices. Proceedings of Public- and Private-Sector Policy Implications of Research on the Economics of Herbicide Resistance Management. https://www.farm foundation.org/webcontent/Public-Policies-Research-and-theEconomics-of-Herbicide-Resistance-Management-1868.aspx. Accessed January 7, 2015

Hill et al.: Postmanagement seed viability • 117 
Deen W, Hunt T, Swanton CJ (1998) Influence of temperature, photoperiod, and irradiance on the phonological development of common ragweed (Ambrosia artemisiifolia). Weed Sci 46: $555-560$

Dekker J, Dekker B, Hilhorst H, Karssen C (1996) Weedy adaption in Setaria spp. IV. Changes in the germinative capacity of S. faberii embryos with development from anthesis to after abscission. Am J Bot 83:979-991

Dodd J (1989) Phenology and seed production of variegated thistle, Silybum marianim (L.) Gaertn, in Australia in relation to mechanical and biological control. Weed Res 29:255-263

Egley GH (1976) Germination of developing prickly sida seeds. Weed Sci 24:239-243

Gill NT (1938) The viability of weed seeds at various stages of maturity. Ann Appl Biol 25:447-456

Gomez R, Liebman M, Munkvold G (2014) Weed seed decay in conventional and diversified cropping systems. Weed Res 54:13-25

Griffin JL, Boudreaux JM, DK Miller (2010) Herbicides as harvest aids. Weed Sci 58:355-358

Hill EC, Renner KA, Sprague CL (2014) Henbit (Lamium amplexicaule), common chickweed (Stellaria media), shepherd's-purse (Capsella bursa-pastoris), and field pennycress (Thlaspi arvense): fecundity, seed dispersal, dormancy, and emergence. Weed Sci 62:97-106

Huang JZ, Shrestha A, Tollenaar M, Deen W, Rahimian H, Swanton CJ (2001) Effect of temperature and photoperiod on the phenological development of common lambsquarters. Weed Sci 49:500-508

Issacs MA, Murdock EC, Toler JE, Wallace SU (1989) Effects of late-season herbicide application on sicklepod (Cassia obtusifolia) seed production and viability. Weed Sci 37:761-765

Jayasuriya KMGG, Baskin JM, Geneve RL, Baskin CC (2007) Seed development in Ipomoea lacunosa (Convolvulaceae), with particular reference to anatomy of the water gap. Ann Bot 100:459-470

Llewellyn RS, Powles, SP (2001) High levels of herbicide resistance in rigid ryegrass (Lolium rigidum) in the wheat belt of Western Australia. Weed Technol 15:242-248

Martinkova Z, Honek A, Lukas J (2011) Viability of Taraxacum officinale seeds after anthesis. Weed Res 51:508-515

McErlich AF, Boydston RA (2013) Current State of Weed Management in Organic and Conventional Cropping Systems. Publications from USDA-ARS/UNL Faculty. Paper 1387. http://digitalcommons.unl.edu/usdaarsfacpub/1387. Accessed January 7, 2015

Myers MW, Curran WS, VanGessel MJ, Calvin DD, Mortensen DA, Majek BA, Karsten HD, Roth GW (2004) Predicting weed emergence for eight annual species in the northeastern United States. Weed Sci 32:913-919

Peters J (2000) Tetrazolium Testing Handbook. Contribution No. 29 to the Handbook on Seed Testing. Lincoln, NE: Association of Official Seed Analysts. $32 \mathrm{p}$

Riar DS, Norsworthy JK, Steckel LE, Stephenson DO, Eubank TW, Scott RC (2013) Assessment of weed management practices and problem weeds in the Midsouth United StatesSoybean: a consultant's perspective. Weed Technol 27: 612-622

Senseman SA, Oliver LR (1993) Flowering patterns, seed production, and somatic polymorphism of three weed species. Weed Sci 41:418-425

Shaner DL (2009) Role of translocation as a mechanism of resistance to glyphosate. Weed Sci 57:118-123

Taylor SE, Oliver LR (1997) Sicklepod (Senna obtusifolia) seed production and viability as influenced by late-season postemergence herbicide applications. Weed Sci 45:497-501

Walker ER, Oliver LR (2008) Weed seed production as influenced by glyphosate applications at flowering across a weed complex. Weed Technol 22:318-325

Walsh MJ, Newman P (2007) Burning narrow windrows for weed seed destruction. Field Crop Res 104:24-30

Walsh MJ, Powles SB (2007) Management strategies for herbicide-resistant weed populations in Australian dryland crop production systems. Weed Tech 21:332-338

Walsh MJ, Powles SB (2014) High seed retention at maturity of annual weeds infesting crop fields highlights the potential for harvest weed seed control. Weed Technol 28:486-493

Warwick SK, Black LD (1988) The biology of Canadian weeds. 90. Abutilon theophrasti. Can J Plant Sci 68:1069-1085

Winter DM (1960) The development of the seed of Abutilon theophrasti II. Seed coat. Am J Bot 37:157-161

Received June 23, 2015, and approved September 18, 2015.

Associate Editor for this paper: Muthukumar $V$. Bagavathiannan, Texas A\&M University. 